\title{
Economic Impact of Cultural Events ${ }^{1}$
}

Melville Saayman \& Andrea Saayman

Institute of Tourism and Leisure Studies and School of Economics, Risk Management and International Trade, North-West University, Potchefstroom Campus

\begin{abstract}
The phenomenon of events can hardly be described as a new one. The aim of this paper is to determine the economic benefits of three major cultural events in South Africa to the host community. Measuring the economic impact normally entails some estimation of the cash injection into a region by visitors and applying the relevant multiplier to arrive at a monetary estimate of the economic impact. But few regions or municipal areas have detailed economic data to construct a type of input-output model and derive a multiplier. The purpose of the methods used in this research were firstly to determine the estimated cash injection, secondly to estimate the size of leakages in the local economy and thirdly to derive an appropriate multiplier to estimate the economic impact of the event.
\end{abstract}

JEL Z11

1

Introduction

Throughout history, events have been an important feature of people's lives. The first Olympic Games were held in Ancient Greece in $776 \mathrm{BC}$ and countless religious events and festivals have been held throughout the ages across the globe (Jago \& Shaw, 1998: 21; Trigg, 1995: 136). In the mid-19 $9^{\text {th }}$ century, Thomas Cook built his reputation as a travel entrepreneur by organising excursions to the great exhibitions in London and Paris, some of the grandest events of their day (Youell, 1995). What have changed in recent times are the frequency, themes and locations of events. Whereas in the past events were arranged to celebrate a specific happening, events may now be presented in order to meet specific objectives with the emphasis on attracting more tourists/visitors and the expenditure associated with them. The latter is referred to as "new money" that stimulates local economic activity through linkages of tourism with other sectors of the economy (Blake et al., 1979; Burns et al., 1986; Faulkner, 1993; Foley, 1991; Gripaios, 1995).
Major events have been one of the fastestgrowing segments of the tourism industry, with cities and countries vigorously competing to host such events (Booth, 1999; Brown, 2000; Van Heerden, 2003; Kidd, 1994).

Saayman (2004) points out that South Africa, like many other countries (such as Australia), bases its destination marketing efforts on events. This has proved to be very successful and South Africa has experienced a significant increase in the number and size of events both at national and international level. One of the great advantages of events is that it can create a demand in a time that might be regarded as offseason. Therefore it can be regarded as a marketing tool on the one hand but also a generator of income on the other. Other benefits or objectives of events include the following:

- Increased community pride and spirit.

- Strengthening of traditions and values.

- Greater participation related to the theme of the event. 
- Adaptation of new social patterns or cultural forms through exposure at the event.

- Marketing benefits, which include branding and creation of a positive image.

- Increased volunteerism and community group activity.

- Intercultural interaction and co-operation.

- Economic benefits (Ritchie, 1984 and Getz, 1997: 44).

This paper focuses on the last of the above points and aims to determine the economic impact of the three largest arts festivals that are held annually in the Republic of South Africa. In order to achieve this, the article is organised in the following fashion, namely: the introduction will be followed by a review of the related literature, an explanation of the method of research and a discussion of the results of the analysis. Thereafter the conclusions and recommendations will be presented.

\section{2}

\section{Literature review}

In the context of event tourism, economic impact is defined as the net economic change in a host community that results from spending attributed to a cultural event. The purpose of an economic impact analysis is to measure the economic benefits that accrue to a community (Van Heerden, 2003; Fayos-Sola, 1997: 242). In its broadest sense, this concerns the enhancement of the way of life, economy and environment of the host population. Getz (1993) therefore rightfully indicates that festivals and events play a significant role in enhancing the image of local communities, which could have additional spin-offs like increased investment, for example.

Festivals and events provide important activities and spending outlets for locals and visitors. Small events normally require minimal capital development and take advantage of existing infrastructure. And because it is often locally controlled and volunteer-intensive, a substantial return is earned on a relatively small financial investment (Getz, 1993).
Events can create linkages between people and groups within communities, and between the community and the rest of the world. Numerous events are partially or wholly in the public domain, so community goals and impacts should be prominent in their management. Events have long been viewed as a tool for economic development (Saayman, 2004). As a rapidly growing sector of many developing countries, international tourism has emerged as an important component of export-oriented development programmes (Goodwin et al., 1997, 1998). Proponents of international tourism as a development tool cite numerous potential economic benefits for host countries, including increased foreign exchange earnings, increased employment opportunities, improved socio-economic conditions and a greater market stability than traditional commodity exports (Eadington \& Redman, 1991; Lea, 1988).

A growing body of literature suggests that the costs of mega-events may outweigh the associated benefits (Getz, 1995). Gelan (2003) maintains that the negative impacts include the opportunity cost of taxpayers' money (Mules, 1998); distribution of cost and benefits among residents of the host community (Burns et al., 1986; KPMG 1996; Soutar \& McLeod, 1993; Van Heerden, 2003); and social and economic costs because of displacement effects (Olds, 1998). However, Foley (1991) notes that opinion on the desirability of major events appears to rely more on personal and political conviction rather than on careful appraisal of an event's economic merit. Thus, an economic impact study informs public debate and provides a useful input in the decision-making process. Since event promoters and local politicians justify the use of public funds based on the potential that the event has to generate benefits to the whole community, there is a need to concentrate on quantifiable local economic impacts. However, although there is a good deal of literature output in the field, a consistent and comprehensive methodological framework has not yet been developed (Archer, 1984; Crompton, 1999, Gelan, 2003 and Stynes, 1999b). 
3

Methodology

Measuring the economic impact of events has a well-established but somewhat problematic methodology. This analysis would normally make some estimation of the cash injection into a region by visitors to the event and then apply the relevant multiplier to arrive at a final monetary estimate of the economic impact. The evidence strongly suggested that many events have little direct economic impact on their community or region, largely because they cater mostly for residents. Only when events attract out-of-region visitors do they start to create economic benefits.

The debate on whether to include local spending in the economic impact analysis has attracted a lot of attention. Asking visitors how much they spend, without distinguishing between tourist and visitor spending, results in high numbers and values that sponsors and promoters of the events use to persuade taxpayers (Gelan, 2003: 409). Crompton (1999) indicates that local spending could be included if there is evidence that the event had kept some community members from making trips elsewhere. Gelan (2003) concludes that including local spending in the analysis can enhance the accuracy of the economic impact assessment.

The multiplier is often used in determining the economic impact of visitor spending and Archer (1976) indicates that the multiplier value is the ratio of the direct, indirect and induced changes to the initial direct change in employment, income or output. The direct component is the initial round of spending at businesses in the local economy; the indirect component is the subsequent increase in revenue, employment and income derived from the need to satisfy the initial direct consumption; and the induced impact is the further increases in employment, income and revenue as local wages and salaries increase the level of local consumption (Archer, 1977).

The magnitude of leakages in a local economy determines the size of the multiplier. In order for a country or region to benefit from an event, leakages need to be determined and minimised. Because of leakages, the amount of money available in the community decreases, until it becomes insignificant. A large multiplier means that there are few leakages from the system and that the community benefits more from the expenditure during the event. However, literature relating to economic multipliers indicates that for small regions leakages are high (Ryan, 1996: 343 and Saayman \& Saayman, 2003).

The determination of the relevant multiplier is another area of concern in determining the economic impact, since few regions or municipal areas have detailed economic data to construct a type of input-output model. The input-output model is a popular tool to determine the size of the multiplier and the impact of visitor spending on the economy of a country (see Kottke, 1988; Zhou et al., 1997; Randall \& Warf, 1996 and Saayman et al., 2000). Regional input-output models (RIMS) are helpful tools, often used to determine the extent of multipliers in local economies (see Fretchling \& Hovarth, 1999 and Wang, 1997), but are not available everywhere.

Walpole and Goodwin (2000) are therefore correct when they remark that large-scale techniques are often inappropriate to determine local economic impacts where significant data are often unavailable. They propose the use of direct estimation from primary data sources, obtained through surveys of businesses (supply side) and tourists (demand side).

Getz (1991: 16(1)) has identified another problem with the methodology in assessing the economic benefits of events, namely that very few economic measures examine the costs of hosting an event. Stynes (1999a, 1999b) observes that a variety of methods, ranging from pure guesswork to complex procedures, are used to estimate expenditure, with studies varying extensively in quality and accuracy, as well as aspects of tourism activities covered. Wang and Gittelson (1988) note that economic benefits of festival impact studies are usually not presented in the context of the costs incurred in hosting the events, and that this is typical of tourism impact studies in general. At one level, sponsors of festivals might be satisfied with the 
simple return-on-investment calculations, but such statements do not take into account the full range of costs and benefits, nor how they are distributed.

\subsection{Surveys}

As recommended by Walpole and Goodwin (2000), surveys were conducted amongst tourists and businesses to estimate the demand and supply of products and services at arts festivals. Three demand and supply surveys were administered at the three major arts festivals in South Africa during 2003. The first festival is the Klein Karoo Nasionale Kunstefees (KKNK), held March annually in the small town of Oudtshoorn in the Little Karoo. The second festival is the Grahamstown National Arts Festival (NAF) held annually in the small town of Grahamstown in the Eastern Cape. The third festival of importance is the Aardklop Arts Festival, held annually in Potchefstroom in the North West Province of South Africa.

At each of the three festivals 400 visitor questionnaires were interviewer administered and the "recall method" was used, where respondents have to recall their spending. A destination-based survey was undertaken, where interviews were held on-site during the event. Different sites were chosen to limit response bias towards a certain group of festinos (the local word used to describe festival-goers). The surveys followed a non-probability sampling method, thus respondents were chosen randomly and the survey was distributed over the duration of the festival.

The questionnaire contained questions regarding the demographic details of the respondents and their behaviour during the festival. The aim of these questionnaires was to determine the total expenditure of visitors at the festivals. Key questions asked in the survey included the length of stay at the festival and the expenditure of visitors on different spending components, since Wilson (1984: 88) indicated that these are key determinants of the magnitude of the economic impact of tourist spending, together with the number of visitors. To estimate the number of visitors, the number of tickets sold as well as the average number of tickets bought per person also had to be determined.

As proposed by Gelan (2003), local residents were included in the survey. To determine the expenditure by local residents, the respondents were asked whether they spent more on the items than during a normal week and how much more they spent on the various items.

At each of the festivals a business survey was also conducted, where approximately 50 questionnaires per festival were interviewer administered. The aim of the questionnaire was to determine which businesses benefited from the festival as well as the magnitude of leakages from the economy. To aid in the determination of leakages from the economy, additional information was obtained from the festival organisers on the appropriation of ticket fees and donor fees.

\subsection{Analytical framework}

The framework used in this paper to quantify the local economic impact is based on the framework used by Gelan (2003) and Stynes (1999b). The focus is on the quantifiable elements of the local economic impact analysis and analytical clarity is provided by translating the relationships of spending by different segments of visitors into algebraic formulations. The analytical model is provided in Table 1 (as adapted from Gelan, 2003).

$\mathrm{S}_{\mathrm{j}}$ denotes spending on different categories (j), $\mathrm{N}$ is the total number of tourists, $\mathrm{S}_{\mathrm{i}}$ is the segment's share in total visits and $\alpha_{i, j}$ is the average spending of a member in segment $i$ on expenditure category $\mathrm{j}$. $\mathrm{S}_{\mathrm{i}}$ consists of two segments, namely locals who attend the festival $\left(\mathrm{L}_{\mathrm{s}}\right)$ and tourists attending the festival $\left(\mathrm{V}_{\mathrm{e}}\right) \cdot \mathrm{l}_{\mathrm{v}, \mathrm{j}}$ and $l_{1, j}$ represent average expenditure on category j per tourist and per resident respectively, with $S$ representing total spending. The sum of spending by the festival coordinating committee on different spending categories $\left(\mathrm{S}_{\mathrm{k}}\right)$ is also included to capture the expenditure associated with hosting the festival, as proposed by Getz (1991). 
Table 1

System of equations for estimating local economic impact

\begin{tabular}{|c|c|}
\hline Equation description & Number \\
\hline$S_{j}=N \Sigma_{i} S_{i} \alpha_{i, j}$ & (1) \\
\hline $\mathrm{S}=\mathrm{V}_{\mathrm{e}} \sum_{\mathrm{j}} \lambda_{\mathrm{v}, \mathrm{j}}+\mathrm{L}_{\mathrm{s}} \sum_{j} \lambda_{\mathrm{l}, \mathrm{j}}+\Sigma_{\mathrm{k}} \mathrm{S}_{\mathrm{k}}$ & (2) \\
\hline $\mathrm{V}_{\mathrm{e}}=\phi \mathrm{V}$ & (3) \\
\hline $\mathrm{L}_{\mathrm{s}}=\psi \mathrm{L}$ & (4) \\
\hline$\lambda_{v, j}=\delta_{v, j} \beta_{v, j}$ & $(5)$ \\
\hline$\lambda_{1, j}=\delta_{1, j} \beta_{1, j}$ & (6) \\
\hline$S=\phi V \Sigma_{j} \delta_{v, j} \beta_{v, j}+\psi L \Sigma_{j} \delta_{l, j} \beta_{1, j}+\Sigma_{k} S_{k}$ & $(7)$ \\
\hline $\mathrm{DS}=\sigma_{\mathrm{j}}\left(\phi \vee \Sigma_{\mathrm{j}} \delta_{\mathrm{v}, \mathrm{j}} \beta_{\mathrm{v}, \mathrm{j}}+\psi \mathrm{L} \Sigma_{\mathrm{j}} \delta_{\mathrm{l}, \mathrm{j}} \beta_{\mathrm{l}, \mathrm{j}}+\Sigma_{\mathrm{k}} \mathrm{S}_{\mathrm{k}}\right)$ & (8) \\
\hline$T S=\sigma_{j}\left(\phi V \Sigma_{j} \delta_{v, j} \beta_{v, j}+\psi L \Sigma_{j} \delta_{1, j} \beta_{1, j}+\Sigma_{k} S_{k}\right) \mu$ & (9) \\
\hline
\end{tabular}

Equations (3) and (4) express $\mathrm{L}_{\mathrm{s}}$ and $\mathrm{V}_{\mathrm{e}}$ as proportions of total tourists (V) and total residents (L) respectively, since the relative size of each group will be known only after the survey, and $\phi$ and $\psi$ thus represent the corresponding ratios. Similarly, the amount of expenditure, $\beta_{\mathrm{v}, \mathrm{j}}$ and $\beta_{\mathrm{l}, \mathrm{j}}$, should be weighted using the proportions that are incurred by the local community, $\delta_{\mathrm{v}, \mathrm{j}}$ and $\delta_{\mathrm{l}, \mathrm{j}}$ (equations 5 and $6)$. By substituting equations (3) to (6) into equation (2), the generalised model is defined (equation 7).

A scalar capture ratio, $\sigma_{j}$, is included to account for "imported products" bought by visitors and locals. The capture ratio applies especially to products that are not likely to be made locally (such as petrol) and only retail margins on these items are captured. This capture ratio varies between the different festival locations and the ratio depends on the size and structure of the local economy. Equation 8 thus indicates the direct sales effect on the local economy - the most important economic impact indicator in the local study area. The total sales effect, with the indirect and induced affects included, is obtained by multiplying direct sales with the appropriate multipliers $(\mu)$. This is indicated by equation (9).

\section{4}

Results

\subsection{Background and demographic details}

The Klein Karoo Nasionale Kunstefees (KKNK) takes place annually in Oudtshoorn for 8 days in March/April. It is an Afrikaans festival, which offers visual and performing art, including cabaret, music theatre, classical music, jazz and popular music, and 162100 tickets for performances were sold. It is therefore not surprising that white (89 per cent), Afrikaans-speaking ( 93 per cent) persons are the main attendees at the festival. Of the respondents, 6 per cent were locals, 3 per cent indicated that the festival is not the main reason for their visit to Oudtshoorn and the remaining 91 per cent were visitors at the festival. On average, respondents attend 3.6 shows while at the festival, travel in groups of 4.9 (although paying only for 2.4 persons) and spend 4 nights (4.8 days) at the festival, mostly camping (36 per cent) and with family and friends (22 per cent). Travelling by car is the main mode of transport.

Grahamstown annually hosts the Grahamstown National Arts Festival (NAF) for 9 days in June/July. The NAF was the first major annual arts festival held in South Africa and differs from the other festivals in that the medium is not identified as Afrikaans. The demographics of the festinos therefore also differ markedly, with more than 50 per cent of the respondents being English-speaking and only 56 per cent who are white South Africans. The festival is also more of a "young person's festival", with roughly 60 per cent of respondents being between the ages of 18 and 35 years. Own transport (66.5 per cent) is mostly used to reach the festival and the average travel group is 4.8 (although financially responsible for only 1.8 persons). Visitors spend an average of 5.44 nights (or 6.080 days) at the festival. Almost a third (28 per cent) of the respondents were locals and 65.04 of the visitors indicated they were there solely for the festival. On average a festino attended 4.85 shows while at the festival and in total 95913 tickets were sold. 
The Aardklop National Arts Festival takes place annually in Potchefstroom for 5 days at the end of September. All genres of classical music, theatre, children's and street theatre, dance, cabaret, rock, jazz, literature and visual art are included in the festival, and although the festival focuses on Afrikaans, it accommodates other language activities as well. As with the KKNK, most festinos are Afrikaans-speaking (89 per cent) white South Africans. The respondents travel in groups of 3 (although paying for only 2.5 persons on average) and stay at the festival for 2.5 days (2 nights), mainly with family and friends. 14 per cent of the respondents were locals and 73 per cent of the remaining 86 per cent were there exclusively for the festival. On average, festinos attend 4.5 shows while at the festival and a total of 88567 tickets were sold for the festival.

Table 2 presents a brief summary of the demographic details of festinos at the different festivals.

Table 2

Demographics of festinos

\begin{tabular}{|l|c|c|c|}
\hline & Aardklop & KKNK & NAF \\
\hline Language & Afrikaans & Afrikaans & English \\
\hline $\begin{array}{l}\text { Respondent } \\
\text { breakdown }\end{array}$ & $\begin{array}{c}14 \% \text { locals } \\
86 \% \text { visitors }\end{array}$ & $\begin{array}{c}6 \% \text { locals } \\
94 \% \text { visitors }\end{array}$ & $\begin{array}{c}28 \% \text { locals } \\
72 \% \text { visitors }\end{array}$ \\
\hline $\begin{array}{l}\text { Length of } \\
\text { festival }\end{array}$ & 5 days & 8 days & 9 days \\
\hline $\begin{array}{l}\text { Length of } \\
\text { stay }\end{array}$ & 2.5 days & 4.8 days & 6.1 days \\
\hline \begin{tabular}{l} 
Travel party \\
\hline $\begin{array}{l}\text { Average } \\
\text { number of } \\
\text { tickets } \\
\text { bought per } \\
\text { person }\end{array}$
\end{tabular} & 2.9 & 4.9 & 4.9 \\
\hline $\begin{array}{l}\text { Total } \\
\text { tickets } \\
\text { sold }\end{array}$ & $\mathbf{8 8} \mathbf{5 6 7}$ & $\mathbf{1 6 2} \mathbf{1 0 0}$ & $\mathbf{9 5} \mathbf{9 1 3}$ \\
\hline
\end{tabular}

\subsection{Spending patterns}

While the above Table gives an overview of the total festival statistics, the local and visitor segments need to be separated in order to determine the spending of each segment, as suggested by Gelan (2003). Tables 3 and 4 present the average spending per person of locals and visitors during each of the three festivals. Locals spend an average of R371.25 at the KKNK, R496.56 at NAF and R127.15 per person at Aardklop. The spending is noticeably higher for the festivals with a longer duration. The high involvement of locals in the NAF is also noticeable.

The same trend applies to visitor spending, with its being the highest at the KKNK (R984.97) and NAF (1141.15) and the least at Aardklop (R366.73). Shows, food and accommodation represents the highest spending categories at all the festivals. It should be noted that the item "transport" refers only to transport whilst at the festival (mainly in the form of private entrepreneurs providing transport services) and not to any transport costs incurred while travelling to the festival, since the benefits of travelling cost would normally not incur to a small local community. It is also interesting to note the strong relationship between the length of the festival and the spending on souvenirs. The results also indicate that the visitors spend more than twice as much as locals, and it is therefore understandable that event organisers aim to attract more visitors than locals to the event. 
Table 3

Spending breakdown of locals (South African Rand)

\begin{tabular}{|l|c|c|c|}
\hline Expenditure category & $\begin{array}{c}\text { Aardklop } \\
\text { average spending }\end{array}$ & $\begin{array}{c}\text { KKNK } \\
\text { average spending }\end{array}$ & $\begin{array}{c}\text { NAF } \\
\text { average spending }\end{array}$ \\
\hline Shows & 50.82 & 39.17 & 67.87 \\
\hline Accommodation & 0.00 & 0.00 & 0.00 \\
\hline Food \& Restaurants & 37.38 & 108.83 & 123.50 \\
\hline Transport & 0.58 & 10.20 & 17.23 \\
\hline Alcoholic drinks & 24.85 & 105.50 & 68.68 \\
\hline Non-alcoholic drinks & 10.81 & 31.08 & 19.17 \\
\hline Retail & 10.38 & 18.25 & 82.08 \\
\hline Tobacco & 7.92 & 3.22 & 11.83 \\
\hline Souvenirs & 31.77 & 54.17 & 100.23 \\
\hline Parking & 1.15 & 0.83 & 4.18 \\
\hline Other & 2.31 & 0.00 & 1.78 \\
\hline Total & $\mathbf{1 2 7 . 1 5}$ & $\mathbf{3 7 1 . 2 5}$ & $\mathbf{4 9 6 . 5 6}$ \\
\hline
\end{tabular}

Table 4

Spending breakdown of visitors (South African Rand)

\begin{tabular}{|l|c|c|c|}
\hline Expenditure category & $\begin{array}{c}\text { Aardklop } \\
\text { average spending }\end{array}$ & $\begin{array}{c}\text { KKNK } \\
\text { average spending }\end{array}$ & $\begin{array}{c}\text { NAF } \\
\text { average spending }\end{array}$ \\
\hline Shows & 99.39 & 142.16 & 189.53 \\
\hline Accommodation & 77.34 & 260.85 & 280.46 \\
\hline Food \& Restaurants & 99.07 & 213.22 & 237.68 \\
\hline Transport & 6.65 & 22.12 & 91.06 \\
\hline Alcoholic drinks & 55.49 & 94.83 & 98.93 \\
\hline Non-alcoholic drinks & 25.75 & 55.04 & 26.32 \\
\hline Retail & 25.89 & 59.57 & 82.55 \\
\hline Tobacco & 13.41 & 20.11 & 15.79 \\
\hline Souvenirs & 48.40 & 109.77 & 124.16 \\
\hline Parking & 7.21 & 2.17 & 5.35 \\
\hline Other & 7.52 & 5.13 & 8.69 \\
\hline Total & $\mathbf{3 6 6 . 7 3}$ & $\mathbf{9 8 4 . 9 7}$ & $\mathbf{1 1 4 1 . 1 5}$ \\
\hline
\end{tabular}

The spending of visitors and locals are two inputs in the model, but the model is also extended to include the spending of the festival organising committee. The committee earns income from the rental of souvenir stall space, ticket fees and sponsorships. Their expenditure includes the payment of artists (which absorbs approximately 80 per cent of the ticket fees), the renting of equipment and venues as well as marketing and personnel costs. The proxy that will be used for total spending by the festival committee is the sponsorships earned and the income from the rental of craft market space (R7.1 million for KKNK; R4.2 million for Aardklop; R13 million for NAF), and this will also be subjected to a capture ratio. 


\subsection{Local economic impact analysis}

In addition to the above spending categories, the relative sizes of the groups of locals and visitors also have to be determined as indicated by equations (3) and (4). The total number of visitors $(\mathrm{N})$ is also estimated, and information such as average number of tickets bought per person and the number of people for whom the respondent is financially responsible (since this often differs from the size of the travel party), is used to calculate both the number of festinos and the distribution of festinos between locals and visitors.

The number of festinos is often a point of dispute between festival organisers and more officially derived figures (such as these). Having more visitors is often seen as a component of "prestige" and success, especially in the light of the recent increase in the number of arts festivals and events in general in South Africa. Snowball and Antrobus (2003) thus indicate that it is also necessary to distinguish between visitor numbers and visitor days. Visitor days can be calculated by calculating the number of festinos per day and then summarising the numbers to get the total number of visitor days. Naturally, those festinos who stay 4 days will be counted four times. This is a useful method to employ to compare festivals of different natures more accurately, but it has no effect on the economic impact calculation. A summary of these totals for all three festivals is presented in Table 5 .

Table 5

Total number and distribution of festinos

\begin{tabular}{|l|c|c|c|}
\hline & Aardklop & KKNK & NAF \\
\hline Total number of festinos & $42905(87.2 \%)$ & $108067(100 \%)$ & $35967(100 \%)$ \\
$(\mathrm{N})^{4}$ & & & \\
$\quad$ Visitors $(V)$ & $49204(100 \%)$ & $93306(86.4 \%)$ & $029(80.8 \%)$ \\
$\quad$ Locals $(L)$ & $6299(12.8 \%)$ & $14761(13.6 \%)$ & $6938(19.2 \%)$ \\
Visitor breakdown & $36426(84.9 \%)$ & $90320(96.8 \%)$ & $26213(90.3 \%)$ \\
$\quad$ Due to event $(\phi)$ & $6479(15.1 \%)$ & $2986(3.2 \%)$ & $2816(9.7 \%)$ \\
$\quad$ Other reasons $(1-\phi)$ & 123010 & 540333 & 219401 \\
Visitor days & & & \\
\hline
\end{tabular}

The above table indicates that a high percentage of visitors to Aardklop (15.1 per cent) do not visit Potchefstroom for the primary reason of attending the festival. Potchefstroom is the largest of the three towns and is also situated the closest to Gauteng Province (the economic hub of South Africa). The high percentage of visitors visiting for other reasons can therefore partially be explained by events organisers trying to capitalise on the close proximity to Gauteng, by organising other events, such as conferences and sport activities, to coincide with the festival.

The information above is applied to determine the total spending in the local economy (as indicted by equation (7) in Table 1). The results are indicated in Tables 6 and 7. What should be emphasised in Table 6 is the fact that the NAF, which is the oldest of the three festivals and which runs for the largest number of days, shows the greatest economic participation by locals (approximately 10 per cent of total spending). This could be an indication that the locals have taken ownership of the festival, which is important from a sustainability and social impact point of view.

The calculation should capture spending only in the local community and therefore the value of $\mathrm{d}_{\mathrm{l}, \mathrm{j}}$ and $\delta_{\mathrm{v}, \mathrm{j}}$ should be determined for each spending category. Because the towns which host the festivals are relatively small and remote (especially Oudtshoorn and Grahamstown), all the values of $\delta_{1, j}$ and $\delta_{v, j}$ are taken as unity, except for accommodation and show tickets. For accommodation $\delta_{1, j}$ is zero and for show tickets the value of both $\delta_{1, j}$ and $\delta_{\mathrm{v}, \mathrm{j}}$ is taken as 0.2 , since spending on the tickets occurs mostly prior to the festival and via Computicket (a national ticketing agency). The value of 0.2 was chosen because festival organisers indicated that almost 80 per cent of ticket income goes to performing artists (of which an insignificantly small portion is locals). 


\section{Table 6}

Estimated local expenditure ${ }^{5}\left(R^{\prime} 000\right)$ according to category for the three arts festivals

\begin{tabular}{|l|c|c|c|c|c|r|}
\hline Category & \multicolumn{2}{|c|}{ Aardklop } & \multicolumn{2}{c|}{ K KN K } & \multicolumn{2}{c|}{ NAF } \\
\hline & Local & Visitor & Local & Visitor & Local & Visitor \\
\hline Shows & 64.0 & 724.1 & 462.5 & 10271.7 & 376.7 & 3974.5 \\
\hline Accommodation & 0.00 & 2817.3 & 0.00 & 23560.4 & 0.00 & 7351.7 \\
\hline $\begin{array}{l}\text { Food \& } \\
\text { Restaurants }\end{array}$ & 235.5 & 3608.5 & 1606.5 & 19258.4 & 856.8 & 6230.3 \\
\hline Transport & 3.6 & 242.2 & 150.6 & 1998.0 & 119.6 & 2387.1 \\
\hline Alcoholic drinks & 156.5 & 2021.4 & 1557.3 & 8565.3 & 476.5 & 2593.1 \\
\hline $\begin{array}{l}\text { Non-alcoholic } \\
\text { drinks }\end{array}$ & 68.1 & 938.1 & 458.8 & 4970.8 & 133.0 & 689.9 \\
\hline Retail & 65.4 & 943.0 & 269.4 & 5380.2 & 569.5 & 2163.9 \\
\hline Tobacco & 49.9 & 488.3 & 47.5 & 1816.6 & 82.1 & 413.8 \\
\hline Souvenirs & 200.1 & 1763.1 & 799.6 & 9914.2 & 695.4 & 3254.6 \\
\hline Parking & 7.3 & 262.5 & 12.3 & 195.7 & 29.0 & 140.4 \\
\hline Other & 14.5 & 273.8 & 0.00 & 463.2 & 12.4 & 227.8 \\
\hline Total & $\mathbf{8 6 5 . 0}$ & $\mathbf{1 4 0 8 2 . 4}$ & $\mathbf{5 0 1 7 . 5}$ & $\mathbf{7 8 6 9 1 . 0}$ & $\mathbf{3 0 6 8 . 4}$ & $\mathbf{2 6 4 4 6 . 3}$ \\
\hline
\end{tabular}

A summary of the results of the local economic impact of all three festivals is indicated in Table 7. The scalar of capture ratios applied relied strongly on the information obtained from the organisers (on the distribution of food, beverage stalls and souvenir stalls between locals and nonlocals and the employment of services from nonlocals in organising the festivals) as well as the information from the business survey, where the percentage of stock that is bought outside the town for various businesses is determined (see Appendix 1). Because all the towns are small to medium-sized towns with little or no industry, most of the products sold are "imported" from other areas. The mark-up assumed is 30 per cent for all the categories, except restaurants, where a 50 per cent markup is accepted. The capture ratios thus apply to the categories of food and restaurants, alcoholic drinks, non-alcoholic drinks, retail, tobacco, souvenirs and festival committee expenses. These ratios for each festival are indicated in Table 7 and a weighted average capture ratio is calculated by weighting the capture ratios of all categories according to the importance of the spending category.

\section{Table 7}

Local economic impact for the three arts festivals

\begin{tabular}{|l|c|c|c|}
\hline & Aardklop & KKNK & NAF \\
\hline Total sales (7) & 14947.4 ('000) & 83708.1 ('000) & 2914.7 ('000) \\
Capture ratios: & & & 0.48 \\
$\quad$ Food \& restaurants & 0.60 & 0.49 & 0.20 \\
Alcoholic drinks & 0.52 & 0.39 & 0.54 \\
$\quad$ Non-alcoholic drinks & 0.64 & 0.63 & 0.34 \\
$\quad$ Retail & 0.42 & 0.47 & 0.30 \\
Tobacco & 0.30 & 0.30 & 0.40 \\
Souvenirs & 0.40 & 0.40 & 0.70 \\
Organising expenses & 0.80 & 0.80 & 0.65 \\
Weighted average & 0.69 & 0.66 & 27574.0 ('000) \\
Direct sales effect (8) & 1233.6 ('000) & 59835.9 ('000) & 1.15 \\
Multiplier & 1.52 & 1.43 & 31710.1 ('000) \\
Total sales effect (9) & 18747.1 ('000) & 8556.3 ('000) \\
\hline
\end{tabular}


The most problematic choice was the choice of multiplier, since using large-scale techniques like the input-output model would be inappropriate for such small areas and no regional input-output models are available. The information obtained from the business survey, in which the leakage factor for various businesses (as determined by the percentage of stock purchased outside the town in question) was determined, was an attempt to get a more realistic view on the amount of funds that the town retains after the initial expenditure (the indirect effect). The type of multiplier that should be applied is the sales multiplier, which is defined by Pollock et al. (1994) as ("the additional local economic impacts as monies are re-spent by local merchants to purchase supplies and services"). A larger multiplier would thus indicate a greater economic impact on the area. For example, if a town "imports" 60 per cent of their stock from outside the town, a R1 million spending in the business sector would leave only roughly R400 000 for consecutive rounds of spending in the town. This is an exaggerated example which assumes that all income earned is used to buy stock and no money is spent on wages, for example (see Snowball \& Antrobus, 2003).

The average leakage factor was high, as expected. In Potchefstroom, the average leakages are 66 per cent, in Oudtshoorn, 70 per cent and in Grahamstown, 87 per cent. This is applied as the input to the multiplier used in the analysis (see Table 7). The basic Keynesian multiplier definition is applied as a rough estimate of the value of the multiplier. The multiplier is derived by means of the following formulae: Multiplier $=1$ /leakages, where the average leakages (as determined by the business surveys) are used as the proxy leakages. The resulting multipliers are 1.52 for Aardklop, 1.43 for KKNK and 1.15 for NAF.

Potchefstroom, which is the largest of the three towns, also has the largest multiplier. Table 7, however, indicates that KKNK generates the most revenue by far, even though it has a smaller multiplier than Aardklop. The town of Oudtshoorn thus benefits significantly more from the arts festival than Potchefstroom. Grahamstown, which is the smallest town, loses most of the economic benefit owing to the substantial leakages from the local economy.

5

\section{Conclusion}

The aim of this paper was to determine the economic impact of the three major arts festivals in South Africa on the respective host communities. The literature review reflected on the problems pertaining to the methodology of determining the economic benefit of events. Two areas of controversy are the application of the correct multiplier and the issue of whether local spending should be included. It became clear that the availability of economic data to determine the multiplier and the controversial issue of which spending to include and which to exclude, make it almost impossible to apply the same methodology to all events.

The spending summary indicated that the length of the event, and therefore the length of stay, has a significant impact on the magnitude of visitor spending. Most of the visitor spending at arts festivals is on show tickets, food, accommodation and souvenirs. It became evident that visitors spend on average almost twice the amount that locals spend at the festival. Visitors also spend on a wider variety of activities than locals. Festivals that attract a larger percentage of locals therefore have a lower total spending and thus a lower impact.

In addition to the distribution between locals and visitors, there also seems to be some relationship between the age of festinos and their spending. The NAF runs for the most consecutive days and the average time spent at the festival is also the longest. Yet the NAF on average attracts a younger festino than the KKNK. The spending per festino at the KKNK is therefore greater than at the NAF, although less time is spent at the festival.

While spending at the festival is an important determinant of the magnitude of the economic impact, the amount received by local businesses is equally important. The results from the business survey indicated that the smaller towns have higher leakages, resulting in lower capture ratios and lower multipliers. The indirect and 
induced effects of spending on events are therefore significantly smaller for small towns.

A comparison of the three arts festivals makes it clear that the KKNK generates the most income. The sheer size of the festival in terms of ticket sales and total festinos makes it the festival with the largest impact, even though it has lower capture ratios than larger towns.

\section{Endnotes}

1 The authors would like to thank the following people/institutions:

- National Research Foundation, who supported the project financially

- Prof Geoff Antrobus and Ms Jen Snowball from Rhodes University who handled the NAF survey and report.

- Prof Christo Boshoff from University of Port Elizabeth who assisted in the KKNK survey.

2 The expenditure categories correspond with $\beta_{1, j}$

3 The expenditure categories correspond with $\beta_{\mathrm{v}, \mathrm{j}}$

4 The appropriate symbol, as defined in Table 1, is indicated in brackets. Note that locals are already accepted as being a weighted population $\left(\mathrm{L}_{\mathrm{s}}=\psi \mathrm{L}\right)$, since the question was phrased so as to ask about the additional spending due to the festival.

5 The expenditure categories again correspond with $\beta_{1, j}$ and $\beta_{\mathrm{v}, \mathrm{j}}$, while local spending per category is represented by $\psi \mathrm{L} \delta_{1, j} \beta_{1, j}$ and $\phi \mathrm{V} \delta_{\mathrm{v}, \mathrm{j}} \beta_{\mathrm{v}, \mathrm{j}}$

\section{References}

1 ARCHER, B. (1976) "Uses and abuses of multipliers", in Gearing, G.E.; Swart, W.W. \& Var, T. (eds.) Planning for Tourism Development: Quantitative Approaches: 115-32, Praeger: New York.

2 ARCHER, B. (1977) Tourism Multipliers: The State of the Art, University of Wales Press: Cardiff.

3 ARCHER, B. (1984) "Economic impact: Misleading multiplier”, Annals of Tourism
Research, 11: 517-18.

4 BLAKE, C.; McDOWELL, S. \& DEVLEN, J. (1979) The 1978 Open Championship at St. Andrews: An Economic Impact Study, Scottish Academic Press: Edinburgh.

5 BOOTH, D. (1999) "Gifts of corruption? Ambiguities of obligation in the Olympic movement", Olympika: The International Journal of Olympic Studies, 8: 43-68.

6 BROWN, G. (2000) "Emerging issues in Olympic sponsorship: Implications for host cities", Sports Management Review, 3: 71-92.

7 BURNS, J.; HATCH, J. \& MULES, T. (1986) The Adelaide Grand Prix: The Impact of a Special Event, Centre for South Australian Economic Studies: Adelaide, South Australia.

8 CROMPTON, J. (1999) "Measuring the economic impact", Working Paper, available on Internet http://rptsweb.tamu.edu/faculty/ crompton.htm.

9 EADINGTON, W.R. \& REDMAN, M. (1991) "Economics and tourism", Annals of Tourism Research, 18: 41-56.

10 FAULKNER, H. (1993) "Evaluating the impacts of hallmark events", BTR Occasional Paper No. 16, Bureau of Tourism Research: Canberra.

11 FAYOS-SOLA, E. (1997) "The impact of megaevents”, Annals of Tourism Research, 25(1): 24144.

12 FOLEY, P. (1991) "The impacts of world student games on Sheffield", Environment and Planning C: Government and Policy, 9: 65-78.

13 FRETCHLING, D.C. \& HORVATH, E. (1999) "Estimating the multiplier effects of tourism expenditure on a local economy through a regional input-output model", Journal of Travel Research, 37(4): 324-33.

14 GELAN, A. (2003) "Local economic impacts: The British Open”, Annals of Tourism Research, 30(2): 406-25.

15 GETZ, D. (1991) "Assessing the economic impacts of festivals and events: Research issues", Journal of Applied Research, 16(1): 61-77.

16 GETZ, D. (1993) "Festivals and special events", in Khan, M.A.; Olsen, M.D. \& Var, T. (eds.) Encyclopaedia of Hospitality and Tourism: 789810, Van Nostrand Reinhold: New York.

17 GETZ, D. (1997) Event Management and Event Tourism, Cognizant Communication Corporation: USA.

18 GOODWIN, H.; KENT, I.J.; PARKER, K.T. \& WALPOLE, M.J. (1997) Tourism, Conservation and Sustainable Development: Volume III, 
Komodo National Park, Indonesia, Department for International Development (unpublished): London.

19 GOODWIN, H., KENT, I.J.; PARKER, K.T. \& WALPOLE, M.J. (1998) “Tourism, conservation and sustainable development: Case studies from Asia and Africa", in Wildlife and Development Series No. 12, International Institute for Environment and Development: London.

20 GRIPAIOS, P. (1995) "The local economic impact of a major sporting event: The case of the Benson and Hedges Open at St Mellion Cornwall”, Discussion Paper No. 120, South Western Economic Research Center, Plymouth Business School, University of Plymouth.

21 JAGO, L.K. \& SHAW, R.N. (1998) "Special events: A conceptual and definitional framework", Festival Management and Event Tourism, 5(1/2): 21-33.

22 KIDD, B. (1994) "Comments on 'Swimming with the Big Boys?', Sporting Traditions, 11(1): 25-29.

23 KOTTKE, M. (1988) "Estimating economic impacts of tourism", Annals of Tourism Research, 15: 122-33.

24 KPMG. (1996) Business, Economic and Social Review of the 1996 IndyCar Event, KPMG: Brisbane.

25 MULES, T. (1998) "Taxpayer subsidies for major sporting events", Sport Management Review, 1(1): 25-43.

26 OLDS, K. (1998) "A special event as part of an urban renewal strategy", Festival Management and Event Tourism, 11: 2-46.

27 POLLOCK, K.H.; JONES, C.M. \& BROWN, T.L. (1994) "Angler survey methods and their application in fisheries management", American Fisheries Society Special Publication, 25: 255-66.

28 RANDALL, J.E. \& WARF, B. (1996) "Economic impacts of AAG conferences", Professional Geographer, 48(3): 272-84.

29 RITCHIE, B. (1984) "Assessing the impacts of hallmark events: Conceptual and research issues", Journal of Travel Research, 23(1): 2-111.

30 RYAN, C. (1996) "Economic impacts of small events: estimates and determinants - a New Zealand example", Tourism Economics: 339-52.

31 SAAYMAN, M. (ed.) (2001) An Introduction to Sports Tourism and Event Management, Leisure Consultants and Publications: Potchefstroom.

32 SAAYMAN, A.; SAAYMAN, M. \& NAUDé, W.A. (2000) "The impact of tourist spending in
South Africa: Spatial implications", South African Journal of Economic and Management Sciences, 3(3): 369-86.

33 SAAYMAN, M. \& SAAYMAN, A. (2003) "International and African tourism markets for South Africa: An economic analysis", Africa Insight, 33(1/2): 93-8.

34 SAAYMAN, M. (2004) An Introduction to Sport and Event Tourism ( $2^{\text {nd }}$ ed.), Leisure C Publications: Potchefstroom.

35 SNOWBALL, J.D. \& ANTROBUS, G.G. (2003) "Economic valuation of the 2003 Grahamstown National Arts Festival: Economic impact, business and household surveys", Rhodes University (Unpublished report): Grahamstown.

36 SOUTAR, G. \& McLEOD, P. (1993) "Residents' perceptions on impact of the Americas Cup", Annals of Tourism Research, 20: 571-82.

37 STYNES, D. (1999a) "Approaches to estimating the economic impacts of tourism: Some examples", Economic Bulletin, available on Internet http//www.msu.edu/rstynes/.

38 STYNES, D. (1999b) "Economic impact concepts and methods", available on Internet http://www.msu.edu/rstynes/.

39 VAN HEERDEN, A. (2003) "Economic impact of the Aardklop National Arts Festival”, Unpublished Masters dissertation, Potchefstroom University for Christian Higher Education Potchefstroom.

40 WALPOLE, M.J. \& GOODWIN, H.J. (2000) "Local economic impacts of Dragon tourism in Indonesia", Annals of Tourism Research, 27(3): 559-76.

41 WANG, P.C.M. (1997) "Economic impact assessment of recreation services and the use of multipliers: A comparative examination", Journal of Park and Recreation Administration, 15(2): 32-43.

42 WANG, P. \& GITTELSON, R. (1988) "Economic limitations of festivals and other hallmark events", Leisure Industry Report: 4-5, August.

43 WILSON, G.D.H. (1984) “"n Ekonomiesgeografiese analise van die toerismebedryf in die Thabazimbi-omgewing", Unpublished masters dissertation, Potchefstroom University for Christian Higher Education: Potchefstroom.

44 YOUELL, R. (1995) Leisure and Tourism (2 ${ }^{\text {nd }}$ ed.), Longman GNVQ: England.

45 ZHOU, D.; YANAGIDA, J.F; CHAKRAVORTY, U. \& LEUNG, P. (1997) "Estimating economic impacts from tourism", Annals of Tourism Research, 24(1): 76-89. 


\section{Appendix 1}

Business survey results

\begin{tabular}{|l|c|c|c|c|c|c|}
\hline & \multicolumn{2}{|c|}{ Aardklop } & \multicolumn{2}{c|}{ NAF } & \multicolumn{2}{c|}{ KKNK } \\
\hline Type of business & $\begin{array}{c}\text { \# respon- } \\
\text { dents }\end{array}$ & $\begin{array}{c}\text { \% stock } \\
\text { bought } \\
\text { outside }\end{array}$ & $\begin{array}{c}\text { \# respon- } \\
\text { dents } \\
\text { \%ought } \\
\text { outside }\end{array}$ & $\begin{array}{c}\text { \# respon- } \\
\text { dents }\end{array}$ & $\begin{array}{c}\text { stock } \\
\text { bought } \\
\text { outside }\end{array}$ \\
\hline Guesthouse & 3 & 22.5 & 0 & 0 & 4 & 21.9 \\
\hline Bookshop & 2 & 95 & 1 & 95.5 & 2 & 95 \\
\hline Bottle store & 5 & 19 & 3 & 95.5 & 4 & 51.2 \\
\hline Boutique & 6 & 85 & 4 & 95.5 & 2 & 95 \\
\hline Butchery & 1 & 85 & 1 & 95.5 & 2 & 35 \\
\hline Café/Takeaways & 5 & 51 & 6 & 65.5 & 4 & 52.5 \\
\hline Cycle shop & 1 & 95 & 0 & 0 & 1 & 95 \\
\hline Florist & 1 & 95 & 1 & 95.5 & 3 & 91.7 \\
\hline Gift shop & 1 & 85 & 1 & 75.5 & 2 & 51.3 \\
\hline Hardware store & 1 & 95 & 2 & 90.5 & 3 & 91.7 \\
\hline Other & 5 & 52 & 8 & 94.3 & 10 & 67.5 \\
\hline Petrol station & 2 & 65 & 2 & 95.5 & 2 & 95 \\
\hline Pharmacy & 3 & 95 & 2 & 95.5 & 2 & 95 \\
\hline Restaurant/Coffee shop & 8 & 62.5 & 11 & 79.1 & 5 & 87 \\
\hline Supermarket & 90 & 2 & 95.5 & 4 & 75 \\
\hline
\end{tabular}

